\title{
KINERJA APARATUR KELURAHAN DALAM PELAYANAN PUBLIK BERBASIS APLIKASI LAIKA
}

\author{
Darma, La Ode Abdul Harlan, Murniati \\ Program Studi Ilmu Pemerintah, Fakultas Ilmu Sosial dan Ilmu Politik, Universitas Muhammadiyah \\ Kendari, email: dharmadar365@gmail.com
}

Program Studi Ilmu Pemerintah, Fakultas Ilmu Sosial dan Ilmu Politik, Universitas Muhammadiyah Kendari, email: harlanlaode@gmail.com

Program Studi Ilmu Pemerintah, Fakultas Ilmu Sosial dan Ilmu Politik, Universitas Muhammadiyah Kendari, email: murniati@umkendari.ac.id

\begin{abstract}
The Kendari City Integration Service (LAIKA) is a manifestation of the Kendari City government's commitment to utilizing technology acceleration in the government sector, which is expected to be able to provide optimal public service performance. This study describes the contribution of government agency apparatus resources in the process of implementing technology-based public services at the subdistrict level. The research approach is descriptive qualitative. Sources of data obtained through observation, interviews, and document studies. The findings in this study indicate that the performance of public services by employees at the Wawowanggu Lurah office has shown serious efforts in order to provide the best service to the community. Even though the limitations of experts are still something that must be pursued in order to optimize the use of applications in order to realize better public services.
\end{abstract}

Keyword: public services; LAIKA; Wawowanggu Subdistrict

\begin{abstract}
Abstrak
Layanan Integrasi Kota Kendari (LAIKA) merupakan wujud komitmen pemerintah Kota Kendari dalam memanfaatkan akselerasi teknologi di bidang pemerintahan diharapkan mampu menghadirkan kinerja pelayanan publik yang optimal. Penelitian ini menjelaskan tentang kontribusi sumber daya aparatur lembaga pemerintahan dalam proses penerapan pelayanan publik berbasis teknologi di level Kelurahan. Pendekatan penelitian secara deskriptif kualitatif. Sumber data diperoleh melalui observasi, wawancara, dan studi dokumen. Temuan dalam penelitian ini menunjukan bahwa kinerja pelayanan publik oleh para pegawai di kantor Lurah Wawowanggu telah menampilkan upaya yang serius agar bisa memberikan pelayanan terbaik kepada masyarakat. Sekalipun keterbatasan tenaga ahli masih menjadi hal yang harus diupayakan agar bisa mengoptimalkan penggunaan aplikasi demi mewujudkan pelayanan publik yang lebih baik.
\end{abstract}

Kata kunci: kinerja pegawai; pelayanan publik; program LAIKA; Wawowanggu subdistrict 


\section{Pendahuluan}

Pelayanan publik berbasis e-government merupakan upaya pemerintah mewujudkan layanan yang berkualitas, profesional, dan akuntabel. Hal ini sebagai bagian dari penerapan prinsip penyelenggaraan pemerintahan yang baik (good governance) (Aini, 2019). Olehnya itu, pemerintah diharapkan mampu menyiapkan berbagai instrumen strategis yang mendukung kebijakan tersebut, seperti regulasi, anggaran, infrastruktur dan sumber daya manusia (Nugraha, 2018).

Sumber daya aparatur pemerintahan memiliki peran penting. Tugas utama mereka adalah memberikan pelayanan kepada masyarakat, sehingga baik buruknya pelayanan yang dihasilkan merupakan cerminan kinerja aparat yang akan berimplikasi pada kinerja organisasi secara menyeluruh (Oktavisatrika et al., 2019). Kinerja merupakan output kerja yang dihasilkan oleh seseorang dalam masa waktu tertentu berupa penetapan target atau sasaran, kriteria dan standar hasil kerja yang sebelumnya disepakati bersama (Rivai \& Basri, 2005). Semua itu membutuhkan kesiapan aparat dalam penguasaan teknologi dasar dan didukung dengan tersedianya perangkat computer dan jaringan internet yang memadai (Hadi et al., 2020).

Pemanfaatan teknologi di bidang pelayanan publik direspon oleh pemerintah kota Kendari dengan menghadirkan program Layanan Integrasi Kota Kendari (LAIKA). Aplikasi LAIKA adalah aplikasi pelayanan pengurusan surat-surat administrasi kependudukan pada setiap kelurahan di Kota Kendari. Program ini ditujukan untuk memudahkan masyarakat mengetahui informasi persyaratan pelayanan, proses pengajuan pelayanan dan penerbitan surat-surat (laika.kendarikota.go.id). Aplikasi LAIKA hadir sebagai jawaban untuk meningkatkan layanan publik di tingkat kelurahan yang selama ini dinilai belum maksimal dan membutuhkan digitalisasi dalam tata kelola pemerintahan (Zainal, 2019). Salah satu keunggulan aplikasi LAIKA adalah durasi waktu yang lebih singkat dalam pengurusan administrasi karena setiap kantor Lurah telah terhubung dengan aplikasi LAIKA termasuk di kelurahan Wawowanggu. Dengan demikian, masyarakat hanya membutuhkan waktu kurang dari tujuh menit untuk menyelesaikan urusan administrasinya. 
Namun penerapan tata kelola layanan publik berbasis teknologi menjadi tantangan baru bagi aparatur pemerintahan. Sistem kerja yang berubah mengharuskan adanya peningkatan kemampuan dan kualitas kerja. Sejumlah penelitian menunjukan masih kurangnya pengetahuan dan kemampuan aparatur dalam memanfaatkan teknologi (Mayowan, 2019). Kondisi ini terjadi diantaranya karena mereka kurang mendapatkan pelatihan terkait teknologi dan juga belum ada motivasi di dalam dirinya untuk mempelajari hal-hal baru (Oktavisatrika et al., 2019). Selain itu sosialisasi kepada masyarakat juga masih kurang sehingga berdampak pada rendahnya pengetahuan publik terkait perubahan pelayanan yang telah beralih ke perangkat teknologi (Attamimi \& Ahamad, 2020). Padahal keinginan dan harapan masyarakat sebagai pengguna layanan merupakan bagian dari pemenuhan kualitas pelayanan (Nasution, 2004).

Kehadiran teknologi ini diharapkan dapat memberikan kualitas pelayanan publik yang lebih baik sehingga mampu memenuhi unsur-unsur pokok di dalam konsep kualitas yaitu kecepatan, ketepatan, keramahan dan kenyaman (Nasution, 2004). Selain itu, aparatur juga memiliki peran yang sangat penting untuk meningkatkan kemampuan diri dalam penguasaan teknologi sehingga akan berdampak positif terhadap kualitas layanan (Ali, 2020). Kualitas layanan publik yang baik bisa diukur dari daya tanggap, jaminan, bukti fisik, empati, dan keandalan (Parasuraman, 2001). Oleh karena itu, artikel ini mengkaji tentang bagaimana kinerja aparatur pemerintahan dalam menjalankan aktivitas pelayanan publik berbasis aplikasi yang diharapkan mampu memberikan pelayanan prima sehingga memberikan efek kepuasan bagi publik pengguna. Sejumlah indikator digunakan untuk mengukur kinerja pegawai seperti tanggung jawab, mutu dan hasil kerja, serta keahlian atau skill pegawai (Suyuti, 2002). 


\section{Metode Penelitian}

Penelitian ini menggunakan pendekatan desktriptif kualitatif yakni suatu metode memosisikan peneliti sebagai instrument kunci yang akan menelusuri objek secara alamiah (Sugiyono, 2016). Informan penelitian sebanyak 10 orang yang terdiri dari unsur pegawai kantor Lurah Wawowanggu dan warga. Pengumpulan data merupakan prosedur yang dilakukan secara sistematis dan sesuai standar untuk memperoleh informasi terkait masalah penelitian (Arikunto, 2002). Olehnya itu di dalam penelitian menggunakan penelitian lapangan (field research), yakni suatu proses pengumpulan data yang diperoleh di lokasi penelitian sehingga data bersifat empiris sesuai dengan masalah yang diteliti.

Langkah praktis pengambilan data melalui observasi langsung ke kantor Lurah Wawowanggun untuk melihat kinerja pegawai dalam memberikan pelayanan publik yang menggunakan aplikasi Laika. Selanjutnya dilakukan aktivitas wawancara kepada para informan yang telah ditetapkan untuk mendalami masalah penelitian. Langkah terakhir dalam pengumpulan data, yakni melalui studi dokumen yakni mengumpulkan data bersumber dari berbagai literatur dan dokumen lainnya.

Tahapan berikutnya adalah menganalisis data yang telah terkumpul. Hal ini dimaksudkan untuk mengetahui atau menjawab pokok permasalahan penelitian. proses analisis data dilakukan dengan reduksi data, yakni pengelompokan data sesuai tem penelitian, kemudian disusun secara sistematis. Tahapan selanjutnya adalah penyajian data untuk mempermudah dalam memahami dan menemukan hubungan antar data. Tahap terakhir adalah penarikan kesimpulan yang didasarkan pada pola yang sudah disusun dan terlihat hubungan dan kecenderungannya. 


\section{Hasil Penelitian dan Pembahasan}

Penelitian ini menjelaskan tentang kinerja aparatur pemerintah di kantor Lurah Wawowanggu yang menggunakan aplikasi Laika dalam pelayanan publik. Adapun temuan penelitian diuraikan berdasarkan indikator sebagai berikut:

\section{Tanggung Jawab}

Tanggung jawab dimaknai sebagai suatu sikap pegawai terhadap pekerjaan yang diberikan. Pekerjaan merupakan amanah yang harus dilaksanakan sesuai dengan prosedur dan jangka waktu tertentu. Pegawai juga harus memperlihatkan motivasi kerja yang tinggi dan kepedulian terhadap pemeliharaan fasilitas kantor.

Tanggung jawab yang baik akan menghasilkan kesan positif di mata publik. Masyarakat yang dilayani akan merasa puas dengan pelayanan yang diberikan karena terpenuhinya tanggung jawab dan kepatuhan aparatur terhadap peraturan yang berlaku. Tanggung jawab sebagai dimensi penilaian kinerja organisasi harus memiliki sistem akuntabilitas pegawai yang baik, dan selalu terbuka kepada publik tentang keberadaan organisasi.

Berdasarkan data hasil wawancara, dapat disimpulkan bahwa pegawai kantor lurah Wawowanggu memiliki rasa tanggung jawab terhadap tugas yang diberikan sehingga dapat dikerjakan dengan baik. Bentuk penyelesaian tugas dapat dilihat dalam bentuk hasil laporan kerja dan dokumentasi lainnya. Selain itu pola kerja juga dibangun berdasarkan tupoksi masing-masing dan mengoptimalkan pemberdayaan kerja sesuai potensi dan kemampuan pegawai serta dukungan sarana dan fasilitas yang tersedia.

Oleh karena itu dari hasil pengamatan peniliti bahwa jika pegawai diberikan tanggung jawab kepada atasannya sesuai dengan tupoksinya dikerjakan dengan sungguh-sungguh sesuai dengan kemampun yang dimilikinya karena kinerja seorang 
pegawai dapat dinyatakan selesai jika adanya hasil kerja yang telah dilaporkan kepada atasan .

Dengan demikian pelaksanaan disiplin dalam meningkatkan kinerja pegawai di Kantor Kelurahan Wowawanggu berupa tercapainya tanggung jawab untuk mengerakkan segala daya dan potensi pegawai yang dapat dimanfaatkan secara optimal yang mengarah pekerjaan dan tugas yang harus dipertanggung jawabkan terutama yang berhubungan dengan tupoksi masing-masing.

\section{Mutu dan Hasil Kerja}

Mutu dan hasil kerja yaitu semua pekerjaan yang dapat memberikan hasil yang baik. Penyelenggaraan berbagai tugas pemerintah yang dilakukan aparatur diharuskan memiliki komitmen terhadap disiplin sebagai kunci untuk meningkatkan produktivitas kerja.

Mengenai kualitas layanan kinerja pegawai di Kantor Kelurahan Wowawanggu berupa tercapainya mutu dan hasil kerja pegawai tuntut untuk menyelesaikan pekerjaan secepat mungkin. Adapun indikator yang ingin diukur dalam dimensi ini adalah tercapainya kualitas layanan dalam menyelesaikan pekerjaan dimana pegawai senantiasa diharapkan mampu menyelesaikan tugas dan pekerjaan yang dibebankan kepadanya sesuai waktu yang telah disepakati atau ditetapkan bersama yang sesuai dengan pedoman kerja yang ada sehingga akan memberikan dampak yang positif terhadap kualitas layanan dalam suatu organisasi

Berdasarkan data wawancara, dapat disimpulkan bahwa kinerja pegawai di Kantor Kelurahan Wowawanggu berupa mutu dan hasil kerja belum memuaskan diantaranya karena masih terdapat pegawai yang belum mampu menyelesaikan pekerjaan tepat waktu disebabkan oleh kendala jaringan, padahal ada tuntutan agar setiap pekerjaan dapat diselesaikan secepat mungkin dengan kualitas dan volume yang memuaskan sesuai dengan prosedur dan standar operasional. 
Namun proses komunikasi diantara pegawai terbilang baik. Segala kendala yang ada dihadapi bersama dan saling memberikan dukungan demi tercapainya pelayanan yang lebih baik kepada masyarakat. Selain itu, secara berkala digelar rapat koordinasi atau semacam evaluasi setiap tiga bulan mengenai bagaimana pelayanan yang sudah kita lakukan kepada masyarakat. Melalui rapat maka akan muncul saran dan masukan jika terdapat pegawai pelayanan yang belum bisa melakukan pelayanan dengan baik.

\section{Keahlian atau Skill}

Setiap pekerjaan membutuhkan keahlian tertentu agar pekerjaan yang dibebankan dapat dijalankan dan mencapai tujuan organisasi dengan baik. Keahlian berkaitan dengan kompetensi inti untuk setiap bidang keilmuan. Keahlian berupa suatu keterampilan yang dimiliki pegawai untuk memperlancar pekerjaan pelayanan. Kualitas pelayanan memerlukan tingkat disiplin yang tinggi, sikap disiplin berperan penting dalam menumbuhkan dan memelihara suasana tertib, aman, harmonis yang memungkinkan pegawai dapat bekerja produktif secara professional.

Penilaian kemampuan kerja dapat diketahui dengan menggunakan pengetahuan dan keahlian, yang dijabarkan dalam bentuk kemampuan mengatasi masalah ditempat kerja, kemampuan berpikir untuk menyelesaikan tugas dengan berbagai macam pekerjaan, kemampuan bekerja dengan luwes, kemampuan memecahkan masalah dengan baik, kemampuan mengajarkan tugas yang kompleks, mampu mempelajari dan meningkatkan pengetahuan tentang pekerjaan baru, semangat dan berprestasi dalam menjalankan tugas, kemampuan menguasai bidang tugas yang diberikan, kemampuan bekerja keras, dan kemampuan menyelesaikan pekerjaan secara mandiri.

Adapun temuan penelitian tentang keterampilan atau skill kerja pegawai di kantor kelurahan Wawowanggu, dapat disimpulkan bahwa ada upaya menciptakan keahlian pegawai yang ditempuh melalui keterlibatan mereka pada pelatihan- 
pelatihan dan pendidikan termasuk dalam penerapan aplikasi LAIKA, sehingga pegawai bisa merealisasikan tanggung jawab pelayanan publik kepada masyarakat. Selain itu, lembaga juga mendorong para pegawai untuk memenuhi tututan termasuk peningkatan kemampuan di bidang teknologi informasi. Pendisiplinan dalam berbagai bentuk pelatihan yang berorientasi pada peningkatan pengetahuan, sikap, dan perilaku mereka sehingga diharapkan secara sukarela para pegawai dapat bekerja secara kooperatif, serta meningkatkan prestasi kerjanya.

Namun temuan peneliti di lapangan menunjukan bahwa keahlian pegawai yang ada dalam melakukan pelayanan masih standar. Dengan demikian kualitas kinerja pegawai di Kelurahan Wowawanggu berupa keahlian melalui berbagai pelatihanpelatihan dan pendidikan masih kurang.

\section{Simpulan}

Berdasarkan temuan pada penelitian ini, maka dapat disimpulkan kinerja pegawai pada kantor Lurah Wawowanggu sesuai indikator berikut ini; pertama, Tanggung jawab. Para pegawai telah memiliki rasa tanggung jawab terhadap pekerjaan yang diberikan. Hal ini dapat diukur dengan adanya upaya sungguhsungguh dari mereka untuk melaksanakan dan menyelesaikan pekerjaan sesuai waktu yang telah ditentukan berdasarkan prosedur dan standar operasional. Kedua, Mutu hasil kerja. Para pegawai belum mampu memenuhi standar kepuasan terhadap mutu hasil kerja yang dihasilkan. Penyebabnya antara lain karena masih terdapat pegawai yang belum mampu menyelesaikan pekerjaan tepat waktu disebabkan oleh kendala jaringan, padahal ada tuntutan agar setiap pekerjaan diselesaikan secepat mungkin dengan kualitas dan volume yang memuaskan sesuai dengan prosedur dan standar operasional. Ketiga, keahlian atau skill. Secara umum keahlian atau skill pegawai di dalam menggunakan teknologi masih terbatas, sekalipun telah dilakukan berbagai pendidikan dan pelatihan. 


\section{Ucapan Terima Kasih}

Penulis ucapkan terima kasih kepada seluruh pihak yang telah membantu hingga penelitian ini selesai. Kepada para narasumber terima kasih telah meluangkan waktu dalam proses wawancara dan mahasiswa yang telah membantu untuk memperoleh data penelitian. Selanjutnya kepada editor jurnal Parabela yang telah memberi kesempatan bagi penulis untuk mempublikasikan artikel ini.

\section{Referensi}

Aini, N. (2019). Evaluasi Kinerja Pegawai Untuk Mewujudkan Pelayanan Publik Dalam Perspektif Good Governance. Jurnal Inovasi Ilmu Sosial Dan Politik, 1(1), 43. https://doi.org/10.33474/jisop.v1i1.2671

Ali, M. (2020). Pengaruh Kompetensi Dimoderasi Oleh Teknologi Informasi Komunikasi Terhadap Kinerja Pelayanan Publik. Sebatik, 24(1), 81-86. https://doi.org/10.46984/sebatik.v24i1.918

Arikunto, S. (2002). Prosedur Penelitian. Rineka Cipta.

Attamimi, U., \& Ahamad, R. G. (2020). Dampak Penggunaan Teknologi Website Terhadap Peningkatan Kualitas Layanan Publik Pada Kantor Camat Kadia Kota Kendari. Journal Publicuho, 3(3), 372. https://doi.org/10.35817/jpu.v3i3.14011

Hadi, K., Asworo, L., \& Taqwa, I. (2020). Inovasi Dialogis: Menuju Transformasi Pelayanan Publik Yang Partisipatif (Kajian Sistem Pelayanan Malang Online). Journal of Government and Civil Society, 4(1), 115. https://doi.org/10.31000/jgcs.v4i1.2438

Mayowan, Y. (2019). DI DESA ( Studi Kasus di Kabupaten Lamongan ). 23.

Nasution, M. N. (2004). Manajemen Jasa Terpadu : Total Service Management. PT. Ghalia Indonesia.

Nugraha, J. T. (2018). E-Government Dan Pelayanan Publik (Studi Tentang Elemen Sukses Pengembangan E-Government Di Pemerintah Kabupaten Sleman). Jurnal Komunikasi Dan Kajian Media, 2(1), 32-42.

Oktavisatrika, G. W., Muchsin, S., \& Abidin, A. Z. (2019). PROBLEMATIK PELAYANAN PUBLIK APARATUR PEMERINTAH KELURAHAN (Studi Kasus Di Kantor Kelurahan Bandulan Kecamatan Sukun Kota Malang). Respon Publik, 13(6), 31-38. http://www.riset.unisma.ac.id/index.php/rpp/article/view/4445 
Parasuraman, A. V. (2001). Delivering Quality Service. The Free Press.

Rivai, \& Basri. (2005). Performance Appraisal: Sistem yang Tepat untuk Menilai Kinerja Karyawan dan Meningkatkan Daya Saing Perusahaan. Raja Grafindo Persada.

Sugiyono. (2016). Metode Penelitian Kualitatif Kuantitatif dan R\&D. Alfabeta.

Suyuti. (2002). Penilaian Prestasi Kerja Sektor Pemerintahan. Gannesha.

Zainal, A. S. (2019). Layak Huni Yang Berbasis Ekologi , Informasi Dan Teknologi. 10-19.

https://laika.kendarikota.go.id/ 